\title{
Marketable and Marketed Surplus and Price Spread of Vegetables in Phek District, Nagaland
}

\author{
Praveen Dukpa* and T. Zarenthung Ezung \\ Department of Economics Nagaland University, Lumami \\ *Corresponding author: praveenptrck5@gmail.com (ORCID ID: 0000-0003-2663-6202)
}

Received: 24-02-2021 Revised: 22-04-2021 Accepted: 28-05-2021

\begin{abstract}
Vegetables are part and parcel of the daily healthy human diet. There will always be a demand for the vegetables in the market; the supply side has to keep up with the demand. With this regard, the study was carried out in Phek district, Nagaland, where the production and marketing of vegetables are well recognized. Three primary vegetables, cabbage, beans, and potato, were selected for the study from twelve villages from the sample population of 300 farmers in 2016-2017. The study was carried out to find out the marketable, marketed surplus, and the price spread in the marketing of the selected vegetables. Three marketing channels were observed, where Channel I (Farmer to consumer) played a significant role in terms of net returns received by farmers, lower cost, and non-existence of price gap. The result shows that the production, marketable surplus, and marketed surplus of cabbage was found to higher than beans and potato. To enhance and boost up production and marketed surplus, it is recommended to prioritize Channel I, infrastructural development, and extension services.
\end{abstract}

\section{Highlights}

(0 The paper aims to find out the vegetable marketable and marketed surplus and the various marketing channels and bring out suitable measures and recommendations.

Keywords: Marketable and marketed surplus, Nagaland

Vegetables are an essential component of a person's healthy balanced diet. Vegetables are the primary sources of nutrients such as vitamins A and C, potassium, folic acid, and dietary fiber; consumption of vegetables reduces the risk of several chronic diseases. The vegetable requirement is 280 grams per day for a person (Mike \& Martin, 2009). Besides the nutritional benefits, the production of vegetables improves the economy of the farmers as these are excellent sources of income and employment. There has been and always will be a demand for vegetables in the market; there is immense scope for vegetable production. It is upon the supply to meet up the demand, which significantly depends upon marketable and marketed surplus. According to the market report from IndexBox, the global vegetable production stood at $1,555 \mathrm{M}$ tonnes in
2018-19. India is a leading producer of fruits and vegetables, and today globally, India ranks second in the production of vegetables in the world, next only to China (Shahbandeh, 2021). The production of vegetables in India has increased from 101.2 Million Tonnes to 184.40 Million Tonnes from 200405 to 2017-18 (Horticultural Statistics at a Glance 2018). During 2017-18, the area under vegetables in India was 10.26 Million Hectares with a production of 184.40 Million Tonnes, contributing (59\% - 61\%) in horticulture crop productions since 2012-2013 (NHB, 2018). The contribution of vegetables was more towards developing the horticulture sector

How to cite this article: Dukpa, P. and Zarenthung Ezung, T. (2021). Marketable and Marketed Surplus and Price Spread of Vegetables in Phek District, Nagaland. Economic Affairs, 66(2): 329-333.

Source of Support: None; Conflict of Interest: None $\infty$ 
in India (Kondal, 2016).With its favourable climatic condition, India has immense potential in vegetable production, providing employment and nutritional security. The marketed surplus is as crucial as the production of vegetables. A marketable surplus can be defined as the leftover goods after the consumption, payment in kind and gifts, and donations to others have been met. It is the product which can be sold in the market by the farmers to earn an income.

On the other hand, a marketed surplus is the actual quantity of goods that are being sold in the market. The role at which vegetable production expands determines the pace of agricultural development, while the growth in the marketed surplus determines the pace of economic development. An increase in production must be accompanied by an increase in the marketable surplus for the country's economic development Kumar et al. 2014).

Keeping in view the above points, a study was carried out to find out the marketable, marketed surplus, and price spread in Phek district Nagaland which is well known for vegetable production and marketing

\section{Research Methodology}

The study was carried out in Phek District Nagaland from twelve random villages prominent for producing and marketing vegetables. From the selected villages, 300 random sample farmers were taken into account for the study. Structure and pre-tested questionnaires and interview methods were used to collect the data. The data have been analyzed using statistical techniques; marketable, marketed surplus along with price spread and Net returns estimation have been analyzed using the given following methods:

Marketable surplus (MS) $=$ Total Production $(\mathrm{TP})-$ Consumption (C)

Where consumption includes the overall consumption, payments in goods, donations, gifts, etc.

Marketed Surplus (Mrktd.S) = Marketable Surplus (MS) - Post Harvest losses

Where Post-harvest loss includes all the losses in the transit and in the process of marketing.
Price Spread $(\mathrm{PS})=$ Price paid by the consumer $(\mathrm{PC})$ - Price received by the farmer $(\mathrm{PF})$

Total marketing cost $(\mathrm{TC})=C_{p}+C_{m i}+\ldots \ldots \ldots+\ldots C_{m n}$ Where $C_{p}=$ Marketing cost of the producer $(₹ / \mathrm{q})$ $C_{m i}=$ Marketing cost of $i^{\text {th }}$ Middlemen (₹/q)

Producers' Share $(P S)=(P R / P C) \times 100$

Where $P S=$ producers' share in consumer rupee (₹/q)

$P R=$ price received by the producer $(₹ / q)$

$P C=$ price paid by Consumer (₹/q)

$$
\begin{gathered}
\text { Producers' } \text { Net Price }\left(N P_{P}\right)=G P_{P}-\left\{C_{P}+\right. \\
\left.\left(M L_{P} \times G P_{P}\right)\right\}
\end{gathered}
$$

Where, $N P_{P}=$ Net Price received by the producers (₹/q)

$G P_{P}=$ Gross Price received by the producer (₹/q)

$C_{P}=$ Marketing cost incurred by the producers ( $\left.₹ / q\right)$ $M L_{P}=$ Marketing losses (₹/q)

\section{Findings}

The total area, production, marketable, and marketed surplus of vegetables are presented in table 1 ; where it was observed that from the sample study of twelve villages from Phek district, with a sample population of 300, it was found that the total area under cabbage cultivation was 178 hectare. Beans were cultivated in a total farm size of 150-hectares. The total farm size of potatoes by the farmers in the study area was 189.5 hectares. The total area under cultivation of potato was highest (189.5 hectares), followed by cabbage (178 hectares), and the least was beans (150 hectares).

The total production and productivity of cabbage were higher than that of beans and potato. The total production of cabbage from twelve villages was 25557.85 quintal with productivity of 143.58 quintal per hectare, which is comparatively much higher than that of beans and potato. The potato production is the second-highest among the three vegetables, with a total production of 1048.16 quintals and a productivity of 5.53 quintals per hectare. The production of beans was the least, with a total production of 289.76 quintals and a productivity of 1.93 quintals per hectare. 
After consumption and various other purposes, the total marketable surplus of cabbage was $97.15 \%$ of the total production, followed by potato $77.34 \%$ and beans $56.21 \%$. It can be noticed that the marketable surplus of cabbage is higher because cabbage in Phek district was cultivated for commercialization purposes and beans were least as it was primarily cultivated for consumption purposes.

Due to lack of storage facilities, proper transportation facilities, and handling during the post-harvest and transit, there is a gap between the marketable and marketed surplus. Out of the marketable surplus, only $94.55 \%$ of the cabbages were sold in the market, the marketed surplus. The marketed surplus of potato and beans was $68.41 \%$ and $48.92 \%$ of the total production, respectively. The post-harvest losses and the gap between the marketable and marketed surplus of potato was highest with a loss/gap of $8.93 \%$ because they either rot off due to climatic conditions during transportation and also the farmers do not sell off their entire marketable surplus and keep it in their stock for future requirements.

\section{Marketing Channels, Price Spread, and Net returns}

In the study area, three Marketing Channels were observed for the marketing of cabbage and potato and only two Channels for beans' marketing. Channel I is the Channel where there are no intermediaries, and there are direct connections between the farmers and consumers. Channel II involves the role of intermediaries. In Channel II, the retailers act as a middleman between the producer and the consumer. Channel III involves the role of Wholesaler and Retailer between the producer and the consumer.
Channel I: Producer-Consumer

Channel II: Producer - Retailer- Consumer

Channel III: Producer - Wholesaler- RetailerConsumer

Table 2 presents the overview of Net price, Net margin, price spread of various vegetables in three different channels. As per the finding presented in table 2, the net price received by the farmer was highest in Channel I for all the vegetables where the farmers and the consumers have a direct link with no intermediaries involved. The net price received in Channel I for cabbage was $92.90 \%$ of the consumer rupee, $98.99 \%$ for beans, and $97.42 \%$ for potato. Comparatively, beans had a higher Net price received by the farmers. Channel III received the lowest Net returns for the marketing of cabbage and potato due to higher marketing costs and the involvement of more intermediaries. Cabbage farmers received just $28.89 \%$ of the consumer rupee and potato farmers $41.87 \%$ of the consumer rupee. Channel I for all the vegetables under study had the lowest marketing cost due to the absence of intermediaries ands under study had the lowest marketing cost due to the absence of intermediaries and low quantity of goods sold through Channel I. The marketing cost of the farmers marketing cabbage and potato was highest in Channel III in table 2 .

The price spread/gap, which is the difference between the price received by the farmer and the price paid by the consumer, was found to be nonexistence in Channel I, due to the direct marketing between the consumer and producer with no intermediary. It depicts the marketing efficiency of Channel I, In-Channel II, there is a price gap between the price received by the farmers and the

Table 1: Total Area, Production, Marketable and Marketed Surplus of Vegetables

\begin{tabular}{llll}
\hline Particulars & Cabbage & Beans & Potato \\
\hline Area (in Hectare) & 178 & 150 & 189.5 \\
Production(in Quintal) & 25557.85 & 289.76 & 1048.16 \\
Productivity per hectare & 143.58 & 1.93 & 5.53 \\
Total Consumption (in Quintal) & $729.35(2.85 \%)$ & $126.89(43.79 \%)$ & $237.51(22.66 \%)$ \\
Marketable Surplus (in Quintal) & $24828.50(97.15 \%)$ & $162.87(56.21 \%)$ & $810.65(77.34 \%)$ \\
Losses (in Quintal) & $664.5(2.59 \%)$ & $21.11(7.28 \%)$ & $93.63(8.93 \%)$ \\
Marketed Surplus (In Quintal) & $24164.00(94.55 \%)$ & $141.76(48.92 \%)$ & $717.02(68.41 \%)$ \\
\hline
\end{tabular}

Sources: Field survey 2016-2017 N=300. 
Table 2: Overview of Net price returns, Price spread, and Cost of marketing (Rs/total quantity sold per Quintal)

\begin{tabular}{|c|c|c|c|c|c|c|c|c|}
\hline \multirow{3}{*}{ Intermediaries } & \multicolumn{8}{|c|}{ Study Area Phek District, Nagaland } \\
\hline & \multicolumn{3}{|c|}{ Channel- I } & \multicolumn{3}{|c|}{ Channel -II } & \multicolumn{2}{|c|}{ Channel- III } \\
\hline & Cabbage & Beans & Potato & Cabbage & Beans & Potato & Cabbage & Potato \\
\hline \multirow{2}{*}{$\begin{array}{l}\text { Net price received by } \\
\text { Producer }\end{array}$} & 120300 & 399165 & 533980 & 161300 & 84020 & 537085 & 10617360 & 541740 \\
\hline & $(92.90)$ & (98.99) & $(97.42)$ & $(54.31)$ & $(71.11)$ & $(62.17)$ & $(28.89)$ & $(41.87)$ \\
\hline \multirow[t]{2}{*}{ Net margin of Retailer } & - & - & - & 65150 & 27315 & 173415 & 4657076 & 244750 \\
\hline & & & & $(21.94)$ & $(22.86)$ & $(20.08)$ & $(13.11)$ & $(18.92)$ \\
\hline \multirow{2}{*}{$\begin{array}{l}\text { Net margin of } \\
\text { Wholesaler }\end{array}$} & - & - & - & - & - & - & 11270580 & 261050 \\
\hline & & & & & & & $(31.73)$ & $(20.18)$ \\
\hline \multirow[t]{2}{*}{ Cost of marketing } & 9200 & 4070 & 14150 & 70550 & 8140 & 153335 & 8977984 & 246210 \\
\hline & $(7.10)$ & (1.01) & $(2.58)$ & $(23.75)$ & $(6.81)$ & $(17.75)$ & $(25.27)$ & (19.03) \\
\hline \multirow[t]{2}{*}{ Consumer price } & 129500 & 403235 & 548130 & 297000 & 119475 & 548130 & 35523000 & 1293750 \\
\hline & (100.00) & (100.0) & $(100.0)$ & (100.00) & (100.0) & (100.00) & (100.00) & (100.00) \\
\hline \multirow[t]{2}{*}{ Price Spread } & - & - & - & 118800 & 34515 & 246810 & 23682000 & 661250 \\
\hline & & & & $(40.0)$ & $(28.89)$ & $(28.57)$ & $(66.67)$ & (51.11) \\
\hline
\end{tabular}

Source: Field Survey 2016-2017.

price paid by the ultimate consumers. There is a price spread in channel II due to the involvement of retailers, where they need to get their net margin. In Channel II, the price spread for cabbage marketing was $40 \%$ of the Consumer rupee, $28.89 \%$ for beans, and $28.57 \%$ for potatoes. Due to the price spread in Channel II the Net price received by the farmers gets reduced as compared to Channel I. Channel III has the highest price gap because of multiple intermediaries, wherein the marketing of cabbage there was $66.67 \%$ price spread and $51.11 \%$ price spread in the marketing of potato.

\section{Summary and Conclusion.}

From the study of three major vegetables in Phek District, Nagaland, which is well recognized in terms of production and marketing vegetables, it was found that cabbage was primarily cultivated for commercialization purposes which is depicted by higher marketable surplus and marketed surplus as compared to beans and potato. The potato was cultivated for consumption and commercialization, and bean were cultivated for consumption purposes with the surplus being sold in the market by the farmers. The marketable and marketed surplus of cabbage was 24828.50 (97.15\%) quintal and 24164.00 (94.55\%) quintal, beans 162.87 (56.21\%) quintal and $141.76(48.92 \%)$ quintal, potato 810.65 (77.34\%) quintal and $717.02(68.41 \%)$ quintal. Three Channels of marketing were observed; the Net Price received by the farmers was highest in Channel I, where there is direct marketing, and lowest in Channel III, where there were more intermediaries. The cost of the marketing was found to be lowest in Channel I and highest in Channel III. The price gap was observed in Channel II and Channel III, where there was a significant gap in the price received and the consumer's price. The price spread for cabbage and potato was maximum in Channel III. Therefore, it is recommended that Channel I be given priority, and focus and infrastructure should be developed regarding storage facilities, better road connectivity, and extension services to enhance marketed surplus and reduce the price spread.

\section{REFERENCES}

Baba, S.H. et al. 2010. Marketed Surplus and Price Spread of Vegetables in Kashmir Valley. Agric. Econ. Res. Rev., 23: 15-127.

Deogharia, P.C. 2017. Vegetable Marketing in Jharkhand: A Micro Study of Marketable and Marketed Surplus of Selected Vegetables, Jharkhand J. Dev. Manag. Stud. XISS, Ranchi, 15(4): 7493-7505.

Dukpa, P. and Ezung, T.Z. 2020. Analysis of Vegetable Marketing Efficiency in Phek District, Nagaland. Econ. Aff., 65(3): 427-432.

Joshi, G. 2011. An Analysis of Marketed Surplus and Price Spread of Brinjal in Western Uttar Pradesh. Asian J. Manag. Res., 2(1): 2011.

Kondal, K. 2016. Determinants of Marketed Surplus of Vegetable Growers in Ranga Reddy District: An Econometric Analysis, Agricultural Situation in India, LXXII(10): 40-45. 
Kondal, K. 2017. Determinants of Marketed Surplus of Tomatoes in Telangana State. Int. J. Res. Econ. Soc. Sci. (IJRESS), 7(9): 578-585.

Kumar et al. 2004. Vegetable sector in India: An overview. National Centre for Agricultural Economics and Policy Research, New Delhi.

Melkamu, B. et al. 2017. Determinants of Potato Marketed Surplus Among Smallholder Farmers in Banja District, Awi Zone of Amhara Region, Ethiopia. Int. J. Agric. Econ., 2(4): 129-134.
Nichols, M. and Hilmi, M. 2009. Growing vegetables for home and market. Rural Infrastructure and Agro-Industries Division Food and Agriculture Organization of the United Nations Rome.

Deogharia, P.C. 2017. Vegetable Marketing In Jharkhand: A Micro Study of Marketable and Marketed Surplus of Selected Vegetables, Jharkhand J. Dev. Manag. Stud. XISS, Ranchi, 15(4): 7493-7505. 
